\title{
Pengaruh Kompetensi Karyawan dan Teknologi Informasi pada Kualitas Laporan Keuangan LPD Dengan Pendidikan Sebagai Pemoderasi
}

\author{
A.A. Sg. Istri Pradnya Paramitha ${ }^{1}$ \\ Ida Bagus Dharmadiaksa ${ }^{2}$ \\ ${ }^{1,2}$ Fakultas Ekonomi dan Bisnis Universitas Udayana (Unud), Bali, Indonesia \\ e-mail: pradnya.paramitha13@yahoo.co.id
}

\begin{abstract}
ABSTRAK
Penelitian ini bertujuan untuk mengetahui pengaruh kompetensi karyawan dan teknologi informasi pada kualitas laporan keuangan LPD dengan pendidikan sebagai pemoderasi. Teknik analisis data yang digunakan adalah MRA dengan Uji Selisih Mutlak. Hasil penelitian ini menunjukkan bahwa kompetensi karyawan dan teknologi informasi berpengaruh positif pada kualitas laporan keuangan. Pendidikan tidak mampu memoderasi pengaruh kompetensi karyawan pada kualitas laporan keuangan, namun mampu memoderasi dan memerkuat pengaruh teknologi informasi pada kualitas laporan keuangan. Hasil penelitian ini diharapkan mampu memberikan tambahan informasi pada pihak - pihak yang berkaitan langsung dalam menyusun laporan keuangan untuk menjalankan tugasnya dengan baik sehingga akan mampu menghasilkan laporan keuangan yang berkualitas.

Kata kunci: kualitas laporan keuangan, kompetensi karyawan, teknologi informasi, dan pendidikan
\end{abstract}

\begin{abstract}
This study aims to determine the effect of employee competence and information technology on the quality of LPD financial reports with education as a moderator. The data analysis technique used is MRA with Absolute Difference Test. The results of this study indicate that employee competence and information technology have a positive effect on the quality of financial statements. Education is not able to moderate the influence of employee competence on the quality of financial statements, but is able to moderate and strengthen the influence of information technology on the quality of financial statements. The results of this study are expected to be able to provide additional information to the parties - parties directly related to preparing financial statements to carry out their duties properly so that they will be able to produce quality financial reports.

Keywords: financial report quality, employee competency, information technology, and education
\end{abstract}

\section{PENDAHULUAN}

Lembaga keuangan memiliki peranan penting dalam meningkatkan perekonomian

negara. Berbagai wilayah di Indonesia telah mengembangkan lembaga keuangan lokalnya masing-masing, beberapa diantaranya yaitu Badan Kredit Kecamatan (BKK) di Jawa Tengah, Lembaga Perkreditan Kecamatan (LPK) di Jawa Barat, 
A.A. Sg. Istri Pradnya Paramitha dan Ida Bagus Dharmadiaksa. Pengaruh...

Lumbung Pitih Nagari (LPN) di Sumatra Barat dan Lembaga Perkreditan Desa (LPD) di Bali yang didirikan pada tahun 1984 (Sadiartha, 2017). LPD merupakan lembaga ekonomi desa yang berguna sebagai tempat pengumpulan dana, pemberian kredit, serta sumber pembiayaan dalam pembangunan di wilayah desa yang ada di Bali.

LPD dalam menjalankan manajemennya sama seperti yang dilakukan dalam pemerintahan Desa Adat yaitu berdasarkan kekeluargaan dan dalam proses pelayanan jasa keuangannya dilakukan atas dasar prinsip saling percaya. Pengurus dari LPD itu sendiri ditunjuk berdasarkan hasil musyawarah Desa Adat. Pengurus LPD merupakan warga yang berasal dari tiap Banjar yang berada dalam satu Desa Adat, dan memiliki Badan Pengawas LPD Desa Adat yang terdiri dari seluruh Kelian Banjar di Desa Adat yang bersangkutan.

Pemilihan pengurus LPD melalui musyawarah Desa Adat tersebut menjadi salah satu kelemahan dalam pengelolaan LPD. Hal ini dikarenakan dalam perekrutan pengurus LPD ini tidak melihat bagaimana latar belakang pendidikan yang dimiliki dari masing - masing sumber daya manusia (SDM). Dengan kata lain siapa saja yang mendapat suara terbanyak dapat menjadi pengurus LPD. Hal ini yang menyebabkan pengelolaan LPD tidak berjalan dengan baik bahkan ada yang mengalami kebangkrutan. Berdasarkan Lembaga Pemberdayaan Lembaga Pengkreditan Desa (LPLPD) Kota Denpasar tahun 2016, dari 35 LPD yang ada di Kota Denpasar, 33 LPD dalam kondisi sehat dan 2 LPD dalam kondisi cukup sehat yaitu LPD Serangan dan LPD Oongan. 
Menilai kinerja dari suatu LPD diperlukan laporan keuangan yang baik dan lengkap. Keberhasilan manajemen dalam mengelola suatu entitas atau organisasi dapat tercermin dari laporan keuangan yang dihasilkan. Menurut Kordlouie, et. al, (2014) tujuan utama dibuatnya laporan keuangan adalah untuk menggambarkan kinerja dari suatu perusahaan bisnis dalam membantu stakeholders membuat keputusan ekonomi. Salah satu kasus terkait manipulasi laporan keuangan yaitu dilakukan oleh Ketua LPD Belaluan Kabupaten Gianyar yang terbukti melakukan melakukan tindakan memperkaya diri sendiri yang merugikan keuangan negara (dalam hal ini Kabupaten Gianyar) senilai Rp 1,16 miliar (News Antara Bali dalam Widiutami, dkk., 2017).

Menurut penelitian McDaniel, et. al (2002) dalam Gamayuni (2017) menyebutkan bahwa kualitas laporan keuangan yang baik yaitu laporan keuangan yang dapat menghasilkan informasi berguna bagi pengguna dalam mengambil keputusan ekonomi. Maju tidaknya sebuah LPD salah satunya tergantung dari bagaimana kualitas laporan keuangan yang dihasilkan. Menyusun laporan keuangan yang berkualitas harus memenuhi empat karakteristk kualitatif laporan keuangan yaitu dapat dipahami, relevan, keandalan, dan dapat dibandingkan. Selain itu terdapat beberapa faktor yang dapat memengaruhi kualitas dari laporan keuangan yang dihasilkan, faktor yang digunakan dalam penelitian ini yaitu kompetensi karyawan, pemanfaatan teknologi informasi serta pendidikan yang dimiliki oleh karyawan LPD.

Karyawan merupakan SDM yang sangat berperan penting dalam menyusun laporan keuangan entitas ataupun organisasi, karena dengan 
A.A. Sg. Istri Pradnya Paramitha dan Ida Bagus Dharmadiaksa. Pengaruh...

kemampuan, pengetahuan, serta keterampilan yang dimiliki dapat memudahkan mereka dalam proses penyusunan laporan keuangan serta dapat mengatasi hambatan yang muncul sehingga laporan keuangan yang dihasilkan akan menjadi berkualitas. Hasil penelitian yang dilakukan oleh Hanifa (2016) menyebutkan bahwa kompetensi pengelola keuangan berpengaruh signifikan dan positif terhadap kualitas laporan keuangan. Penelitian Ardiyanto dan Surasni (2016) menunjukkan sumber daya manusia berpengaruh positif terhadap keandalan laporan keuangan. Berbeda dengan hasil penelitian Zuliarti (2012) yang menyebutkan sumber daya manusia tidak berpengaruh terhadap nilai informasi laporan keuangan. Sejalan dengan itu penelitian Aswandi (2018) menunjukkan kompetensi sumber daya manusia berpengaruh negative terhadap kualitas laporan keuangan.

Faktor lain yang juga dapat memengaruhi kualitas dari laporan keuangan yang dihasilkan yaitu teknologi informasi. Pemanfaatan teknologi informasi akan membantu mempercepat proses pengelolaan data transaksi keuangan, penyajian laporan keuangan, serta dapat menghindari kesalahan dalam melakukan posting dari dokumen buku, jurnal, buku besar, hingga menjadi kesatuan laporan keuangan (Soimah, 2014). Menurut penelitian dari Ardiyanto dan Surasni (2016) menunjukkan teknologi informasi berpengaruh positif terhadap keandalan laporan keuangan. Sejalan dengan itu dalam penelitian Nuryanto dan Afiah (2013) menunjukkan pemanfaatan teknologi informasi berpengaruh positif secara simultan terhadap kualitas laporan keuangan. Berbeda dengan hasil penelitian Setyowati dkk., (2016) memaparkan bahwa peran teknologi informasi tidak 
berpengaruh signifikan terhadap kualitas laporan keuangan. Penelitian Hanafi (2013) juga menyatakan bahwa teknologi informasi tidak berpengaruh terhadap nilai informasi pelaporan keuangan, hal ini karena teknologi informasi tidak dimanfaatkan secara optimal.

Penelitian ini merupakan replikasi dari penelitian yang dilakukan oleh Kurniawan, dkk. (2017) yang berjudul Pengaruh Kompetensi Sumber Daya Manusia, Penerapan Teknologi Informasi dan Locus Of Control Terhadap Kualitas Laporan Keuangan Pada Lembaga Perkreditan Desa (LPD) Di Kabupaten Buleleng Barat. Perbedaan antara penelitian ini dengan penelitian sebelumnya yaitu lokasi dari penelitian ini adalah LPD di Kecamatan Denpasar Selatan. Pemilihan lokasi penelitian terkait dengan kondisi dan kemajuan dari masing - masing LPD di Kecamatan Denpasar Selatan yang bervariasi, ada yang sehat dan cukup sehat. Selain itu berdasarkan laporan LPLPD Kota Denpasar Tahun 2015, LPD pada Kecamatan Denpasar Selatan yang paling banyak mengalami kondisi kesehatan yang kurang baik yaitu satu LPD dalam kondisi cukup sehat (LPD Intaran) dan satu LPD dalam kondisi tidak sehat (LPD Serangan). Selanjutnya di Tahun 2016, kondisi LPD pada Kecamatan Denpasar Selatan mengalami peningkatan namun masih terdapat satu LPD dalam kondisi cukup sehat, yaitu LPD Serangan. Penelitian ini juga menambahkan variabel pendidikan sebagai pemoderasi. Alasan menggunakan pendidikan sebagai pemoderasi karena adanya ketidakkonsistenan dari hasil penelitian sebelumnya serta dikarenakan mayoritas pengurus LPD direkrut berdasarkan musyawarah Desa Adat yang belum tentu memiliki latar belakang pendidikan yang sesuai 
A.A. Sg. Istri Pradnya Paramitha dan Ida Bagus Dharmadiaksa. Pengaruh...

dengan bidang yang dikerjakan sehingga menyebabkan pengurus LPD akan menemukan kesulitan dalam melakukan pekerjaannya.

Teori stewardship menggambarkan situasi manajer yang tidak termotivasi pada tujuan-tujuan individu melainkan lebih fokus untuk tujuan dan kepentingan organisasi (Davis, et . al , 1997). Teori ini menekankan dua hal penting yakni kewajiban steward (pengurus LPD) menjalankan amanah yang diberikan principal dengan penuh tanggungjawab untuk mencapai tujuan yang telah ditetapkan, salah satunya mampu menghasilkan laporan keuangan yang berkualitas . Berdasarkan hal tersebut maka dibutuhkan karyawan yang kompeten dalam pengelolaan suatu LPD.

Kompetensi merupakan suatu karakteristik dari seseorang yang memiliki keterampilan, pengetahuan, dan kemampuan untuk melaksanakan suatu pekerjaan (Hevesi, 2005). Sedangkan karyawan merupakan modal yang sangat penting dan strategis dalam kehidupan sebuah perusahaan (Nuryani, dkk., 2018). Jadi dapat diartikan kompetensi karyawan adalah kemampuan dan kemauan SDM untuk melaksanakan tugas dan tanggung jawab yang didelegasikan kepada mereka dengan dukungan pendidikan, pelatihan, dan pengalaman yang memadai (Muda, et al., 2017). Karyawan yang telah memiliki pengetahuan dan pemahaman mengenai apa yang ia kerjakan, akan memaksimalkanya dalam melakukan setiap pekerjaan. Oleh karena itu, dalam hal penempatan tugas, pelatihan, partisipasi, penilaian kinerja, dan kompensasi harus efektif karena akan berdampak terhadap peningkatan kinerja karyawan dalam mencapai tujuan organisasi (Chen, 2009) 
Penelitian Kurniawan, dkk. (2017), Wiranata dkk., (2015), dan Nurilah (2014) dalam penelitiannya menyebutkan kompetensi sumber daya manusia berpengaruh posistif terhadap kualitas laporan keuangan. Sejalan dengan itu penelitian Suliyantini dan Kusmuriyanto (2017) menunjukkan kompetensi sumber daya manusia memiliki pengaruh positif yang tidak signifikan terhadap kualitas laporan keuangan serta dalam penelitian Simon, et. al., (2016) menyebutkan bahwa kompetensi aparatur berpengaruh positif pada kualitas informasi laporan keuangan. Berdasarkan penjelasan di atas, hipotesis yang dapat dirumuskan dalam penelitian ini adalah

$\mathrm{H}_{1}$ : Kompetensi karyawan berpengaruh positif pada kualitas laporan keuangan

Menurut Davis, et. al (1989) dalam Lai (2017), tujuan dasar dari Technology Acceptance Model (TAM) adalah untuk memberikan penjelasan tentang faktor apa saja yang menentukan penerimaan teknologi serta mampu menjelaskan perilaku penggunanya. TAM merupakan salah satu model penelitian paling populer untuk menjelaskan aspek keperilakuan pengguna sistem informasi (Surendran, 2012). Model TAM memprediksi penerimaan pengguna terhadap sistem informasi berdasarkan persepsi kemanfaatan dan persepsi kemudahan penggunaan (Rukmiyati dan Budiartha, 2016).

Teknologi informasi merupakan suatu kombinasi dari teknologi komputerisasi dan komunikasi dalam bentuk sistem perangkat lunak dan perangkat keras (Kelton and Robin, 2010). Berdasarkan teori ini, dengan memanfaatkan teknologi informasi dapat memermudah pekerjaan karyawan dalam mencapai tujuan organisasi ataupun entitas, salah satunya dalam menyusun 
A.A. Sg. Istri Pradnya Paramitha dan Ida Bagus Dharmadiaksa. Pengaruh...

laporan keuangan

Penelitian Kurniawan, dkk. (2017), Wiranata dkk., (2015), Sapitri dkk., (2015), Nurilah (2014), dan Penelitian Adel \& Abdallah (2013) menyebutkan bahwa pemanfaatan teknologi informasi berpengaruh posistif terhadap kualitas laporan keuangan. Berdasarkan penjelasan di atas, hipotesis yang dapat dirumuskan dalam penelitian ini adalah

$\mathrm{H}_{2}$ : Teknologi informasi berpengaruh positif pada kualitas laporan keuangan.

Penelitian Kiranayanti dan Erawati (2016) menunjukkan kompetensi sumber daya manusia berpengaruh positif pada kualitas laporan keuangan. Perbedaan hasil ditemukan oleh Aswandi (2018) yang menyebutkan bahwa kompetensi sumber daya manusia berpengaruh negatif pada kualiatas laporan keuangan. Maka dengan adanya perbedaan hasil penelitian sebelumnya, peneliti menambahkan pendidikan sebagai variabel moderasi.

Tingkat pendidikan memengaruhi kinerja seseorang dalam bekerja, hal ini dikarenakan ilmu yang mereka miliki akan berguna di dunia kerja. Pendidikan yang memadai akan membuat karyawan memiliki kompetensi yang lebih baik dan juga memiliki wawasan yang lebih luas. Karyawan yang berkompeten ditambah memiliki pendidikan yang memadai maka akan membuat kualitas dari laporan keuangan yang dihasilkan juga semakin baik. Penelitian Arismawati dkk., (2017) menunjukkan bahwa tingkat pendidikan berpengaruh positif pada kuliatas laporan keuangan. Pendidikan diduga sebagai variabel moderasi yang dapat memerkuat hubungan kompetensi sumber daya manusia dengan kualitas laporan keuangan. 
Berdasarkan penjelasan tersebut, maka hipotesis yang dapat dirumuskan dalam penelitian ini adalah

$\mathrm{H}_{3}$ : Pendidikan memerkuat pengaruh kompetensi karyawan pada kualitas laporan keuangan.

Pemanfaatan teknologi informasi diperlukan dalam proses penyusunan laporan keuangan, karena dengan memanfaatkan teknologi informasi akan meminimalisir terjadinya kesalahan. Penelitian sebelumnya terkait pemanfaatan teknologi informasi dilakukan oleh Nadir dan Hasyim (2017), Hardyansyah dan Khalid (2016) menyebukan bahwa pemanfaatan teknologi informasi berpengaruh positif pada kualitas laporan keuangan. Namun berbeda dari hasil penelitian Riandani (2017) menunjukkan pemanfaatan teknologi informasi tidak berpengaruh pada kualitas laporan keuangan. Maka dengan adanya perbedaan hasil penelitian sebelumnya, peneliti menambahkan pendidikan sebagai variabel moderasi.

Pendidikan dapat meningkatkan pemahaman pengguna dalam memanfaatkan teknologi informasi dan dapat memudahkan individu dalam penggunaannya. Penelitian Nastiti (2013) juga membuktikan bahwa pendidikan berpengaruh positif secara simultan maupun parsial pada kualitas penyajian informasi akuntansi. Penelitian Irma (2015) membuktikan bahwa pendidikan berpengaruh positif pada kinerja penerapan sistem informasi akuntansi. Pendidikan diduga sebagai variabel moderasi yang dapat memerkuat hubungan pemanfaatan teknologi informasi dengan kualitas laporan keuangan. Berdasarkan penjelasan tersebut, maka hipotesis yang dapat dirumuskan dalam penelitian ini adalah 
A.A. Sg. Istri Pradnya Paramitha dan Ida Bagus Dharmadiaksa. Pengaruh...

$\mathrm{H}_{4}$ : Pendidikan memerkuat pengaruh teknologi informasi pada kualitas laporan keuangan.

\section{METODE PENELITIAN}

Penelitian ini menggunakan pendekatan kuantitatif berbentuk asosiatif yaitu penelitian yang bertujuan untuk mengetahui pengaruh kompetensi karyawan dan teknologi informasi pada kualitas laporan keuangan LPD di Denpasar Selatan dengan pendidikan sebagai pemoderasi. Secara sistematis, desain penelitian yang digunakan pada penelitian ini dapat digambarkan pada Gambar 1.

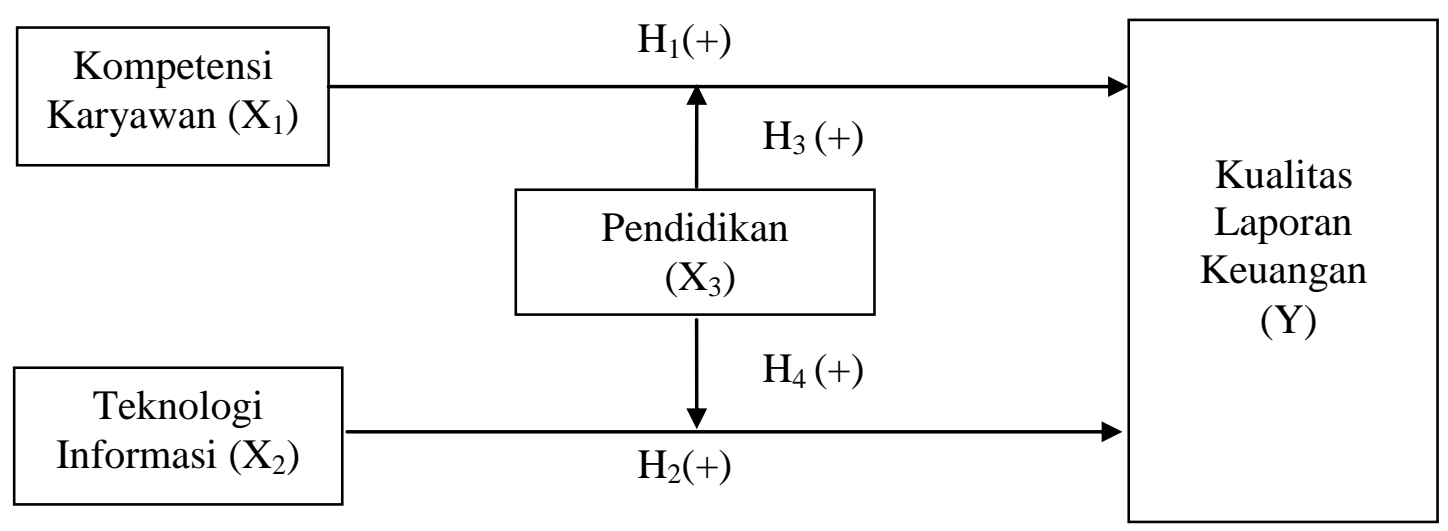

\section{Gambar 1. Desain Penelitian}

Sumber : Data diolah, 2018

Penelitian ini dilakukan pada LPD Kecamatan Denpasar Selatan.

Pemilihan LPD Kecamatan Denpasar Selatan sebagai lokasi penelitian dikarenakan kondisi dari LPD yang berada pada kecamatan ini bervariasi, ada dalam kondisi yang sehat dan juga dalam kondisi cukup sehat. Kondisi inilah yang perlu diamati dan diteliti sehingga diketahui apa saja yang mempengaruhi kemajuan sebuah LPD, salah satunya dengan mengukur kualitas dari laporan keuangan yang dihasilkan. 
Variabel dependen dalam penelitian ini adalah kualitas laporan keuangan (Y), dengan indikator pengukuran yang digunakan yaitu relevan, andal, dapat dibandingkan, dan dapat dipahami. Variabel independen dalam penelitian ini adalah kompetensi karyawan $\left(\mathrm{X}_{1}\right)$ dan teknologi informasi $\left(\mathrm{X}_{2}\right)$. Kompetensi karyawan diukur menggunakan tiga indikator yaitu pengetahuan, ketrampilan, dan sikap. Sedangkan indikator pengukuran variabel teknologi informasi yaitu ketersediaan teknologi informasi, jaringan internet, pemanfaatan jaringan internet, laporan keuangan terkomputerisasi, dan penggunaan software yang sesuai dengan UU. Variabel moderasi pada penelitian ini adalah pendidikan $\left(\mathrm{X}_{3}\right)$, dengan indikator pengukuran yang digunakan yaitu pendidikan formal, kesesuaian jurusan, dan pendidikan non formal.

Populasi dalam penelitian ini adalah seluruh LPD di Kecamatan Denpasar Selatan, yaitu sebanyak 11 LPD. Teknik penentuan sampel yang digunakan dalam penelitian ini adalah sampel jenuh. Sampel jenuh merupakan adalah teknik penentuan sampel bila semua anggota populasi digunakan sebagai sampel. Responden yang digunakan dalam penelitian ini yaitu seluruh pengurus dan karyawan LPD, dengan total responden yaitu sebanyak 55 orang. Daftar jumlah karyawan LPD di Kecamatan Denpasar Selatan dapat dilihat pada Tabel 1. 
Tabel 1.

Data Jumlah Karyawan pada LPD Kecamatan Denpasar Selatan

\begin{tabular}{clc}
\hline No. & \multicolumn{1}{c}{ Nama LPD } & Jumlah Karyawan \\
\hline 1. & LPD Intaran & 38 \\
2. & LPD Kepaon & 25 \\
3. & LPD Panjer & 24 \\
4. & LPD Pedungan & 28 \\
5. & LPD Pemogan & 22 \\
6. & LPD Penyaringan & 14 \\
7. & LPD Renon & 15 \\
8. & LPD Sanur & 9 \\
9. & LPD Serangan & 9 \\
10. & LPD Sesetan & 22 \\
11. & LPD Sidakarya & 22 \\
& $\quad$ Jumlah & 228 \\
\hline
\end{tabular}

Sumber: LPLPD Denpasar, 2018

Jenis data dalam penelitian ini yaitu data kualitatif berupa kuesioner dan

data kuantitatif berupa jawaban dari pernyataan kuesioner yang telah

dikuantitatifkan. Sumber data dalam penelitian ini yaitu data primer berupa

kuesioner yang diberikan kepada responden dan data sekunder berupa daftar nama, alamat, jumlah karyawan LPD di Kecamatan Denpasar Selatan, serta struktur organisasi LPD. Metode pengumpulan data yang digunakan dalam penelitian ini yaitu metode survei dengan menyebarkan kuesioner langsung ke lokasi penelitian berupa pernyataan mengenai pengaruh kompetensi karyawan dan teknologi informasi pada kualitas laporan keuangan LPD dengan pendidikan sebagai pemoderasi.

Hasil kuesioner yang telah terkumpul terlebih dahulu dilakukan uji validitas dan realiabilitas untuk mengetahui apakah jawaban responden tersebut telah dijawab dengan benar atau tidak. Kemudian dilakukan analisis statistik deskriptif, dan uji asumsi klasik yang meliputi uji normalitas, uji multikolinieritas, dan uji heteroskedastisitas, untuk mengetahui apakah model regresi penelitian dapat dikatakan baik. 
Teknik analisis data yang digunakan dalam penelitian ini adalah Moderated Regression Analysis (MRA) dengan Uji Selisih Mutlak. Berdasarkan hasil analisis regresi, selanjutnya dilakukan uji koefisien determinasi R2, uji kelayakan model (uji F) dan uji hipotesis (uji t). Adapun model regresi ditunjukan dalam persamaan sebagai berikut :

$$
\begin{aligned}
& Y=\alpha+\beta_{1} X_{1}+\beta_{2} X_{2}+\beta_{3} X_{3}+\varepsilon \ldots \ldots \ldots \ldots \ldots \ldots \ldots \ldots \ldots \ldots \ldots \ldots \ldots \ldots \ldots \\
& Y=\alpha+\beta_{1} X_{1}+\beta_{2} X_{2}+\beta_{3} X_{3}+\beta_{4} Z_{1}-X_{3}+\beta_{5} Z X_{2}-X_{3}+\varepsilon
\end{aligned}
$$

Keterangan:

$\mathrm{Y} \quad=$ variabel kualitas laporan keuangan

$\mathrm{X}_{1} \quad=$ variabel kompetensi karyawan

$\mathrm{X}_{2} \quad=$ variabel teknologi informasi

$\mathrm{X}_{3} \quad=$ variabel pendidikan

$\mathrm{ZX}_{1} \mathrm{X}_{3}=$ interaksi yang diukur dengan nilai absolut perbedaan antara $\mathrm{X}_{1}$ dan $\mathrm{X}_{3}$

$\mathrm{ZX}_{2} \mathrm{X}_{3}=$ interaksi yang diukur dengan nilai absolut perbedaan antara $\mathrm{X}_{2}$ dan $\mathrm{X}_{3}$

$\alpha \quad=$ konstanta

$\beta_{1}-\beta_{5}=$ koefisien regresi

$\varepsilon \quad=$ standar eror

\section{HASIL DAN PEMBAHASAN}

Uji validitas dilakukan untuk mengukur sejauh mana ketepatan alat ukur yaitu kuesioner dapat mengukur apa yang seharusnya diukur. Berdasarkan uji validitas dapat dilihat bahwa seluruh indikator pernyataan dalam kuesioner memiliki nilai pearson correlation yang lebih besar dari 0,30 sehingga seluruh indikator tersebut telah memenuhi syarat validitas data. Uji reliabilitas dilakukan untuk mengukur konsistensi dan stabilitas jawaban dari pernyataan kuesioner. Berdasarkan uji reliabilitas, nilai cronbach's alpha masing-masing variabel memiliki nilai lebih 
A.A. Sg. Istri Pradnya Paramitha dan Ida Bagus Dharmadiaksa. Pengaruh...

besar dari 0,60. Hal ini menunjukkan bahwa semua pernyataan dalam kuesioner reliabel dan dapat digunakan.

Statistik deskriptif dalam penelitian ini merujuk pada nilai rata-rata (mean) dan simpanan baku (standar deviation), nilai minimum dan maksimum dari seluruh variabel dalam penelitian ini yaitu kualitas laporan keuangan (Y), kompetensi karyawan $\left(\mathrm{X}_{1}\right)$, teknologi informasi $\left(\mathrm{X}_{2}\right)$, serta pendidikan $\left(\mathrm{X}_{3}\right)$. Hasil statistik deskriptif ditunjukkan pada Tabel 2

Berdasarkan Tabel 2 dapat disimpulkan bahwa jumlah pengamatan (N) penelitian ini berjumlah 50 .

Tabel 2.

Hasil Statistik Deskriptif

\begin{tabular}{|c|c|c|c|c|c|c|}
\hline No & Variabel & $\mathbf{N}$ & Min. & Max. & Mean & $\begin{array}{c}\text { Std. } \\
\text { Devias }\end{array}$ \\
\hline 1 & $\begin{array}{l}\text { Kualitas Laporan } \\
\text { Keuangan (Y) }\end{array}$ & 50 & 24 & 36 & 28,74 & 3,155 \\
\hline 2 & Kompetensi Karyawan $\left(\mathrm{X}_{1}\right)$ & 50 & 20 & 32 & 25,78 & 2,838 \\
\hline 3 & Teknologi Informasi $\left(\mathrm{X}_{2}\right)$ & 50 & 16 & 24 & 19,70 & 2,243 \\
\hline 4 & Pendidikan $\left(\mathrm{X}_{3}\right)$ & 50 & 12 & 20 & 15,30 & 1,909 \\
\hline
\end{tabular}

Variabel kualitas laporan keuangan memiliki nilai minimum sebesar 24 dan nilai maksimum sebesar 36 dengan nilai rata-rata sebesar 28,74. Nilai rata-rata sebesar 28,74 dengan standar deviasi sebesar 3,155. Variabel kompetensi karyawan memiliki nilai minimum sebesar 20 dan nilai maksimum sebesar 32 dengan nilai rata-rata sebesar 25,78 dengan standar deviasi sebesar 2,838. Variabel teknologi informasi memiliki nilai minimum sebesar 16 dan nilai maksimum sebesar 24 dengan nilai rata-rata sebesar 19,70 dengan standar deviasi sebesar 2,243. Variabel pendidikan memiliki nilai minimum sebesar 12 dan nilai maksimum sebesar 20 dengan nilai rata-rata sebesar 15,30 dengan standar deviasi sebesar 1,909 . 
Berdasarkan hasil uji normalitas pada penelitian ini diperoleh nilai Asymp. Sig. (2-tailed) sebesar 0,819. Hal tersebut menunjukkan model penelitian ini berdistribusi normal karena nilai Asymp. Sig. (2-tailed) 0,819 lebih besar dari level of significant sebesar 0,05. Hasil uji multikolinearitas penelitian ini diperoleh nilai tolerance dan VIF dari seluruh variabel menunjukkan bahwa nilai tolerance untuk setiap variabel lebih besar dari 0,10 dan nilai VIF lebih kecil dari 10 yang berarti model persamaan regresi bebas dari gejala multikolinearitas. Hasil uji heteroskedastisitas pada penelitian ini menunjukkan nilai signifikansi masingmasing variabel bebas dalam penelitian ini lebih besar dari 0,05 yang menunjukkan bahwa model regresi ini bebas dari gejala heteroskedastisitas.

Pengujian data dalam penelitian ini menggunakan Moderated Regression Analysis (MRA) dengan Uji Selisih Mutlak. Hasil analisis regresi moderasi dapat dilihat pada Tabel 3 .

Tabel 3.

Hasil Analisis Regresi Moderasi

\begin{tabular}{|c|c|c|c|c|c|}
\hline \multirow[b]{2}{*}{ Model } & \multicolumn{2}{|c|}{$\begin{array}{c}\text { Unstandardized } \\
\text { Coefficients }\end{array}$} & \multirow{2}{*}{$\begin{array}{c}\text { Standardized } \\
\text { Coefficients } \\
\text { Beta } \\
\end{array}$} & \multirow[b]{2}{*}{$\mathbf{t}$} & \multirow[b]{2}{*}{ Sig. } \\
\hline & B & Std. Error & & & \\
\hline $\begin{array}{ll}1 & \text { (Constant) }\end{array}$ & 28,415 & 0,283 & & & \\
\hline Kompetensi Karyawan & 0,843 & 0,337 & 0,267 & 2,503 & 0,016 \\
\hline Teknologi Informasi & 1,997 & 0,220 & 0,633 & 9,089 & 0,000 \\
\hline Pendidikan & 0,300 & 0,303 & 0,095 & 0,991 & 0,327 \\
\hline $\mathrm{ZX}_{1}-\mathrm{ZX}_{3}$ & $-0,808$ & 0,504 & $-0,074$ & $-1,605$ & 0,116 \\
\hline $\mathrm{ZX}_{2}-\mathrm{ZX}_{3}$ & 1,016 & 0,275 & 0,187 & 3,691 & 0,001 \\
\hline $\mathrm{R}^{2}$ & & & & & 0,910 \\
\hline Adjusted $\mathrm{R}^{2}$ & & & & & 0,899 \\
\hline $\mathrm{F}_{\text {hitung }}$ & & & & & 88,493 \\
\hline Sig. F & & & & & 0,000 \\
\hline
\end{tabular}

Berdasarkan Tabel 3 dapat disusun persamaan regresi sebagai berikut :

$$
\begin{aligned}
\mathrm{Y}= & 28,415+0,843 \mathrm{X}_{1}+1,997 \mathrm{X}_{2}+0,300 \mathrm{X}_{3}-0,808 \mathrm{ZX}_{1}-\mathrm{ZX}_{3}+ \\
& 1,016 \mathrm{ZX}_{1}-\mathrm{ZX}_{3}+\varepsilon
\end{aligned}
$$


A.A. Sg. Istri Pradnya Paramitha dan Ida Bagus Dharmadiaksa. Pengaruh...

Hasil koefisien determinasi $\left(\mathrm{R}^{2}\right)$ dalam penelitian ini adalah dengan melihat nilai dari Adjusted $\mathrm{R}^{2}$ dengan alasan variabel independen dalam penelitian lebih dari satu dan nilai Adjusted $\mathrm{R}^{2}$ dapat naik turun apabila satu variabel independen ditambahkan ke dalam model. Berdasarkan Tabel 3 menunjukkan bahwa nilai Adjusted $\mathrm{R}^{2}$ yaitu sebesar 0,899. Hal ini berarti bahwa sebesar $89,9 \%$ variasi kualitas laporan keuangan (Y) dapat dijelaskan oleh variabel kompetensi karyawan $\left(\mathrm{X}_{1}\right)$, teknologi informasi $\left(\mathrm{X}_{2}\right)$, pendidikan $\left(\mathrm{X}_{3}\right)$, interaksi $\mathrm{X}_{1}-\mathrm{X}_{3}$, dan interaksi $\mathrm{X}_{2}-\mathrm{X}_{3}$ sedangkan sisanya sebesar $10,1 \%$ dijelaskan oleh variabel lain yang tidak dijelaskan dalam model penelitian.

Uji F pada dasarnya menunjukkan apakah semua variabel independen yang mempunyai pengaruh secara bersama-sama pada variabel dependen. Berdasarkan pada Tabel 3 menunjukkan bahwa nilai signifikansi $\mathrm{F}$ atau $p$-value yaitu sebesar 0,000 lebih kecil dari nilai $\alpha=0,05$. Hasil ini memberikan makna bahwa variabel kompetensi karyawan $\left(\mathrm{X}_{1}\right)$, teknologi informasi $\left(\mathrm{X}_{2}\right)$, pendidikan $\left(\mathrm{X}_{3}\right)$, interaksi $\mathrm{X}_{1}-\mathrm{X}_{3}$, dan interaksi $\mathrm{X}_{2}-\mathrm{X}_{3}$ secara bersama-sama (simultan) berpengaruh pada kualitas laporan keuangan (Y).

Hasil analisis pengaruh kompetensi karyawan pada kualitas laporan keuangan diperoleh nilai $\mathrm{t}$ hitung sebesar 2,503 dengan tingkat signifikansi sebesar 0,016 lebih kecil dari dari nilai $\alpha=0,05$. Hasil ini menunjukkan bahwa $\mathrm{H}_{0}$ ditolak dan $\mathrm{H}_{1}$ diterima, yang mempunyai arti bahwa kompetensi karyawan berpengaruh positif dan signifikan pada kualitas laporan keuangan. Semakin tinggi tingkat kompetensi yang dimiliki karyawan pada LPD Kecamatan Denpasar Selatan maka kualitas laporan keuangan yang dihasilkan akan semakin meningkat. 
Karyawan yang memiliki kompetensi dan keahlian dibidang akuntansi, akan memudahkan karyawan dalam proses penyusunan laporan keuangan serta meminimalisir terjadinya kekeliruan yang akan berdampak terhadap kualitas dari laporan keuangan yang dihasilkan. Temuan ini sejalan dengan penelitian yang dilakukan Agung dan Gayatri (2018), Kiranayanti dan Erawati (2016), serta Hardyansyah dan Khalid (2016) yang menemukan bahwa kompetensi karyawan berpengaruh positif dan signifikan pada kualitas laporan keuangan. Penelitian Hertati (2015) juga menemukan kompetensi sumber daya manusia berpengaruh positif dan signifikan pada kualitas pelaporan keuangan. Sejalan dengan itu, penelitian Setiyawati (2013) menyebutkan bahwa kompetensi akuntan internal berpengaruh positif dan signifikan pada kualitas pelaporan keuangan

Hasil analisis pengaruh teknologi informasi pada kualitas laporan keuangan diperoleh nilai t hitung sebesar 9,089 dengan tingkat signifikansi sebesar 0,000 lebih kecil dari dari nilai $\alpha=0,05$. Hasil ini menunjukkan bahwa $\mathrm{H}_{0}$ ditolak dan $\mathrm{H}_{2}$ diterima, yang mempunyai arti bahwa teknologi informasi berpengaruh positif dan signifikan pada kualitas laporan keuangan. Semakin tinggi tingkat pemanfaatan teknologi informasi dalam proses penyusunan laporan keuangan maka meminimalisir terjadinya kesalahan sehingga akan meningkatkan kualitas dari laporan keuangan yang dihasilkan.

Menurut Sadeghimanesh \& Samadi (2013) menyebutkan bahwa teknologi informasi merupakan bagian integral dan mendasar untuk mendukung, memelihara dan menumbuhkan bisnis, salah satunya dalam menghasilkan laporan keuangan. Memanfaatkan teknologi informasi dapat memudahkan karyawan 
A.A. Sg. Istri Pradnya Paramitha dan Ida Bagus Dharmadiaksa. Pengaruh...

dalam melakukan pengelolaan data dengan lebih cepat dan akurat terkait dengan penyusunan laporan keuangan sehingga akan meningkatkan kualitas laporan keuangan yang dihasilkan. Hal ini sejalan dengan penelitian yang dilakukan Agung dan Gayatri (2018), Nadir dan Hasyim (2017), Sholeh (2017), serta Aniftahudin, dkk., (2016) yang menunjukkan bahwa pemanfaatan teknologi informasi berpengaruh signifikan pada kualitas laporan keuangan. Penelitian Zadeh, et. al (2015) juga menyebutkan teknologi informasi berpengaruh pada kualitas informasi akuntansi.

Hasil analisis interaksi antara variabel kompetensi karyawan pada kualitas laporan keuangan dengan variabel pendidikan menunjukkan nilai t hitung sebesar $-1,605$ dengan tingkat signifikansi sebesar 0,116 lebih besar dari dari nilai $\alpha=$ 0,05. Hasil ini menunjukkan pendidikan tidak mampu memoderasi pengaruh kompetensi karyawan pada kualitas laporan keuangan. Hasil ini menolak hipotesis $3\left(\mathrm{H}_{3}\right)$ yang menyatakan pendidikan memerkuat pengaruh kompetensi karyawan pada kualitas laporan keuangan.

Hasil penelitian ini sejalan dengan dengan penelitian yang dilakukan oleh Murina dan Rahmawaty (2017) menyebutkan bahwa kenyataan di lapangan memperlihatkan tidak semua karyawan yang memiliki tingkat pendidikan yang lebih tinggi paham dalam menyelesaikan permasalahan pada laporan keuangan instansi. Ilmu yang dimiliki karyawan tidak diterapkan dalam proses penyusunan laporan keuangan, dikarenakan karyawan yang memiliki tingkat pendidikan yang lebih tinggi akan menduduki jabatan yang tinggi sehingga tidak terlibat langsung dalam penyelesaian laporan keuangan. Penelitian Muttaqin, dkk. (2014) 
menyebutkan bahwa latar belakang pendidikan karyawan tidak berpengaruh secara signifikan terhadap kinerja karyawan.

Hasil analisis interaksi antara variabel teknologi informasi pada kualitas laporan keuangan dengan variabel pendidikan menunjukkan nilai t hitung sebesar 3,691 dengan tingkat signifikansi sebesar 0,001 lebih kecil dari dari nilai $\alpha=0,05$. Berdasarkan hal tersebut, dapat disimpulkan bahwa $\mathrm{H}_{0}$ ditolak dan $\mathrm{H}_{4}$ diterima, yang mempunyai arti bahwa pendidikan memerkuat pengaruh teknologi informasi pada kualitas laporan keuangan.

Karyawan dengan pendidikan yang memadai akan memudahkan karyawan dalam memahami penyusunan laporan keuangan berbasis komputerisasi. Hal tersebut akan meningkatkan pemanfaatan teknologi informasi dalam proses penyusunan laporan keuangan sehingga kualitas laporan keuangan juga akan meningkat. Hasil penelitian ini sejalan dengan Muzahid (2014) dan Arismawati dkk., (2017) menyebutkan bahwa pendidikan berpengaruh positif terhadap kualitas laporan keuangan. Penelitian Anjani dan Wirawati (2018) menunjukkan bahwa tingkat pendidikan berpengaruh positif terhadap efektivitas pengguna sistem informasi akuntansi.

\section{SIMPULAN}

Berdasarkan hasil pengujian dan pembahasan pada bab sebelumnya, maka dapat disimpulkan bahwa kompetensi karyawan berpengaruh positif pada kualitas laporan keuangan LPD Kecamatan Denpasar Selatan. Hal ini berati bahwa semakin tinggi kompetensi yang dimiliki oleh karyawan, maka akan semakin meningkat kualitas laporan keuangan yang dihasilkan. 
A.A. Sg. Istri Pradnya Paramitha dan Ida Bagus Dharmadiaksa. Pengaruh...

Teknologi informasi berpengaruh positif pada kualitas laporan keuangan LPD Kecamatan Denpasar Selatan. Hal ini berati bahwa semakin tinggi pemanfaatan teknologi informasi dalam proses penyusunan laporan keuangan, maka akan semakin meningkat kualitas laporan keuangan yang dihasilkan.

Pendidikan tidak mampu memoderasi pengaruh kompetensi karyawan pada kualitas laporan keuangan LPD Kecamatan Denpasar Selatan. Hal ini berarti tinggi ataupun rendahnya pendidikan akhir dari karyawan LPD tidak akan berpengaruh pada kompetensi karyawan terhadap kualitas laporan keuangan yang dihasilkan.

Pendidikan memoderasi atau memerkuat pengaruh teknologi informasi pada kualitas laporan keuangan LPD Kecamatan Denpasar Selatan. Hal ini berarti pendidikan mampu meningkatkan pengaruh positif teknologi informasi pada kualitas laporan keuangan. Karyawan yang memiliki pendidikan yang memadai akan lebih mudah dalam memahami penggunaan teknologi informasi dalam proses penyusunan laporan keuangan sehingga kualitas laporan keuangan yang dihasilkan juga akan semakin meningkat.

Berdasarkan simpulan diatas, terdapat beberapa saran yang dapat diberikan yaitu kepada Lembaga Pemberdayaan Lembaga Pengkreditan Desa (LPLPD) Kota Denpasar, disarankan untuk lebih rutin dalam memberikan pendidikan non formal berupa pelatihan - pelatihan kepada karyawan dan pengurus LPD terkait dengan penyusunan laporan keuangan yang baik dan sesuai dengan standar ataupun peraturan baru yang telah ditetapkan sehingga akan membantu dalam menghasilkan laporan keuangan yang berkualitas. 
Kepada pengawas internal LPD Kecamatan Denpasar Selatan, disarankan untuk meningkatkan pengawasan pada LPD yang bersangkutan khususnya terkait dengan penyusunan laporan keuangan sehingga meminimalisir terjadinya kesalahan yang akan berdampak pada kualitas laporan keuangan yang dihasilkan.

Kepada karyawan dan pengurus LPD Kecamatan Denpasar Selatan, disarankan untuk selalu mengikuti pelatihan - pelatihan yang diberikan oleh LPLPD Kota Denpasar terkait dengan penyusunan laporan keuangan, terlebih untuk yang berpendidikan akhir SMA. Hal ini karena dengan mengikuti pelatihan secara rutin, sekalipun berpendidikan akhir SMA, akan membantu dalam meningkatkan kompetensi dan keahlian yang dimiliki oleh karyawan ataupun pengurus LPD sehingga akan mampu menghasilkan laporan keuangan yang berkualitas secara konsisten.

Kepada penelitian selanjutnya, disarankan untuk menggunakan variabel lain selain kompetensi karyawan, teknologi informasi dan pendidikan yang diduga akan berpengaruh pada kualitas laporan keuangan seperti sistem pengendalian internal, komitmen organisasi dan gaya kepemimpinan dan juga disarankan untuk melakukan wawancara langsung kepada karyawan LPD terkait dengan variabel yang diteliti guna untuk memerkuat hasil dari penelitian. Selain itu diharapkan pula untuk memperluas wilayah penelitian yang digunakan, tidak hanya menggunakan satu kecamatan saja melainkan se-Kota Denpasar ataupun se-Bali. Penelitian selanjutnya juga diharapkan untuk membenahi kuesioner pendidikan yang digunakan agar lebih memaksimalkan hasil dari penelitian terhadap variabel pendidikan. 


\section{REFERENSI}

Adel, A., \& Abdallah, J. (2013). The Impact Of Using Accounting Information Systems On The Quality Of Financial Statements Submitted To The Income And Sales Tax Department In Jordan. European Scientific Journal, 1, 41-48. https://doi.org/http://dx.doi.org/10.19044/esj.2013.v9n10p\%25p

Agung, Tut Madiguna dan Gayatri. (2018). Analisis Faktor-Faktor yang Mempengaruhi Kualitas Laporan Keuangan Pemerintah Daerah Kabupaten Karangasem. E-Jurnal Akuntansi Universitas Udayana, 23(2), 1253-1276. https://doi.org/https://doi.org/10.24843/EJA.2018.v23.i02.p17

Aniftahudin, Kamaliah, dan Rheny Afriana H.. (2016). Pengaruh Pemahman Akuntansi, Sistem Informasi Akuntansi Keuangan Pemerintah Daerah dan Teknologi Informasi terhadap Kualitas Laporan Keuangan Pemerintah Daerah (Studi pada skpd Kabupaten Indragiri Hilir). JOM Fekon, 3(1), 935949.

Anjani, Putu Widya dan Ni Gusti Putu Wirawati. (2018). Pengaruh Usia, Pengalaman Kerja, Tingkat Pendidikan, dan Kompleksitas Tugas terhadap Efektivitas Pengguna Sistem Informasi Akuntansi. E-Jurnal Akuntansi Universitas Udayana, 22(3), 2430-2457. https://doi.org/10.24843/EJA.2018.v22.i03.p29

Ardiyanto, H., \& Surasni, N. K. (2016). The Effect Of Information Technology, Adherence To Accounting Rules, and Human Resources on The Reliability Of Financial Statements in Central Lombok District Government, 6(2), 195206. https://doi.org/10.14414/tiar.v6i1.580

Arismawati, K. N., Atmadja, A. T., \& Sulindawati. (2017). Pengaruh Tingkat Pendidikan, Pemahaman Akuntansi Koperasi Berbasis Sak-Etap, Kematangan Usia, Perilaku, Dan Efektivitas Kinerja Terhadap Kualitas Laporan Keuangan Koperasi Simpan Pinjam Di Kabupaten Buleleng. EJournal S1 Ak Universitas Pendidikan Ganesha Jurusan Akuntansi Program S1, 8 .

Aswandi, W. (2018). Pengaruh Kompetensi SDM, Pemanfaatan Teknologi Informasi Akuntansi Dan Pengawasan Terhadap Kualitas Laporan Keuangan Sektor Publik (Studi empiris pada organisasi nirlaba di Kota Padang). Jurnal Akuntansi Universitas Negeri Padang, 6(1), 1-21.

Chen, C.-J. dan J. W. H. (2009). Strategic Human Resource Practices and Innovation Performance - The Mediating Role Of Knowledge Management Capacity. Jornal Of Business Research, 104-114. 
Davis, F. D., Bagozzi, R. P., \& Warshaw, P. R. (1989). User Acceptance of Computer Technology: A Comparison of Two Theoretical Models. Management Science. https://doi.org/10.1287/mnsc.35.8.982

Davis, J. H., Schoorman, F. D., \& Donaldson, L. (1997). Toward a stewardship theory of management. Academy of Management Review, 22(1), 20-47. https://doi.org/10.5465/AMR.1997.9707180258

Gamayuni, R. R. (2017). The Effect of Internal Audit Function Effectiveness and Implementation of Accrual Based Government Accounting Standard on Financial Reporting Quality. Review of Integrative Business and Economics, $7(1), 46-58$.

Hanafi, R. (2013). Analisis Faktor-Faktor Yang Mempengaruhi Nilai Informasi Pelaporan Keuangan Pemerintah Daerah. AKSES Jurnal Ekonomi Dan Bisnis, 8(16), 85.

Hanifa, L. (2016). Pengaruh Kompetensi Pengelola Keuangan dan Sistem Akuntansi Keuangan Daerah Terhadap Kualitas Laporan keuangan. Jurnal Progres Ekonomi Pembangunan, 1(2), 65-80.

Hardyansyah dan Khalid. (2016). Pengaruh Kompetensi Sumber Daya Manusia dan Pemanfaatan Teknologi Informasi Terhadap Kualitas Laporan Keuangan dengan Sistem Pengendalian Intern Sebagai Variabel Moderasi Pada SKPD Kabupaten Polewali Mandar. Jurnal Ilmiah Akuntansi Peradaban, 1(1), 4165 .

Hertati, Lesi. (2015). Competence of Human Resources, The Benefits of Information Technology on Value of Financial Reporting in Indonesia. Research Journal of Finance and Accounting, 6(8), 12-18.

Hevesi, G. A. (2005). Standarts for Internal Control in New York State Government. Retrieved from www.osc.state.ny.us.

Irma, D. P. (2015). Pengaruh Kemampuan Teknik Personal, Program Pelatihan, dan Pendidikan Pemakai, Insentif dan Partisipasi Manajemen pada Kinerja Penerapan Sistem Informasi Akuntansi. Skripsi Universitas Udayana.

Kelton, A. S., Robin R. P., dan B. M. T. (2010). An Effects of Information Presentation Format on Judgement and Decision Making: A Review of the Information System Research. Journal of Information System, 24(2). https://doi.org/10.2308/jis.2010.24.2.79

Kiranayanti, I. A. E., \& Erawati, N. M. A. (2016). Pengaruh Sumber Daya Manusia, Sistem Pengendalian Intern, Pemahaman Basis Akrual Terhadap 
A.A. Sg. Istri Pradnya Paramitha dan Ida Bagus Dharmadiaksa. Pengaruh...

Kualitas Laporan Keuangan Daerah. E-Jurnal Akuntansi, 16(2), 1290-1318.

Kordlouie, H., Mohammadi, F., Naghshineh, N., \& Tozandejani, M. (2014). Role of Accounting Conservatism on the Quality of Financial Statements. International Journal of Business and Management, 9(1), 129-139. https://doi.org/10.5539/ijbm.v9n1p129

Kurniawan, Wikan Maha., Edy Sujana, dan Adi Yuniarta. (2017). Pengaruh Kompetensi Sumber Daya Manusia, Penerapan Teknologi Informasi, dan Locus Of Control Terhadap Kualitas Laporan Keuangan Pada Lembaga Pengkreditan Desa (LPD) di Kabupaten Buleleng Barat. E-Journal Akuntansi Universitas Pendidikan Ganesha, 8(2).

Lai, P. (2017). The Literature Review of Technology Adoption Models and Theories for the Novelty Technology. Journal of Information Systems and Technology Management, 14(1), 21-38. https://doi.org/10.4301/S180717752017000100002

McDaniel, L., Martin, R. D., \& Maines, L. A. (2002). Evaluating financial reporting quality: The effects of financial expertise vs. financial literacy. In Accounting Review. https://doi.org/10.2308/accr.2002.77.s-1.139

Muda, Iskandar, Deni Yuwilia Wardani, Erlina, Azhar Maksum, Ade Fatma Lubis, Rina Bukit, dan Erwin Abubakar. (2017). The Influence of Human Resources Competency and the Use of Information Technology on the Quality of Local Government Financial Report With Regional Accounting System As an Intervening. Journal of Theoretical and Applied Information Technology, 95(20), 5552-5561.

Murina, S., \& Rahmawaty. (2017). Pengaruh Tingkat Pendidikan, Kualitas Pelatihan, Dan Pengalaan Kerja Aparatur Desa Terhadap Pemahaman Laporan Keuangan Desa (Studi Pada Kecamatan Banda Raya Kota Banda Aceh), 2(3), 111-120.

Muttaqin, A. N. dan L. E. T. (2014). Pengaruh Latar Belakang Pendidikan, Masa Kerja, Dan Motivasi Kerja Terhadap Kinerja Karyawan Pada PT. Indocitra Jaya Samudra Negara-Bali Tahun 2013. E-Journal Akuntansi Universitas Ganesha, 4(1).

Muzahid, M. (2014). Pengaruh Tingkat Pendidikan, Kualitas Pelatihan, dan Lama Pengalaman Kerja terhadap Kualitas Laporan Keuangan SKPD. Jurnal Akuntansi, 2(2), 179-196.

Nadir, R., \& Hasyim. (2017). Pengaruh Pemanfaatan Teknologi Informasi , Kompetensi Sumber Daya Manusia , terhadap Kualitas Laporan Keuangan Pemerintah Daerah Dengan Variabel Intervening Standar Akuntansi 
Pemerintahan Berbasis Akrual ( Studi Empiris di PEMDA Kabupaten Barru ). Jurnal Akuntansi Universitas Mullawarman, 14(1), 57-68. https://doi.org/https://doi.org/10.29264/jakt.v14i1.1007

Nastiti, A. D. (2013). Pengaruh Pendidikan, Pelatihan, dan Pengalaman Kerja Terhadap Kualitas Penyajian Informasi Akuntansi (Studi Kasus pada PT Bank Rakyat Indonesia di Kota Magelang). E-Jurnal Akutansi Universitas Dian Nuswantoro, 1-14.

Nurilah. (2014). Pengaruh Kompetensi Sumber Daya Manusia, Penerapan Sistem Akuntansi, dan Pemanfaatan Teknologi Informasi ( Studi Empiris Pada SKPD Kota Depok ). Diponogoro Journal Of Accounting, 3(2), 1-13

Nuryani, Ni Nyoman Juli, Dewa Putu Rida Satrawan, Anak Agung Ngurah Oka Suryadinatha Gorda, L. K. B. M. (2018). Influence of Human Capital, Social Capital, Economic Capital towards Financial Performance \& Corporate Social Responsibility. International Journal of Social Sciences and Humanities, 2(2), 65-76. https://doi.org/10.29332/ijssh.v2n2.128

Nuryanto, M., \& Afiah, N. N. (2013). The Impact of Apparatus Competence, Information Technology Utilization and Internal Control on Financial Statement Quality (Study on Local Government of Jakarta Province Indonesia). World Review of Business Research Issue. Pp, 3(4), 157-171.

Riandani, Riedy. (2017). Pengaruh Kompetensi SDM, Pemanfaatan Teknologi Informasi, dan Pengendalian Intern terhadap Kualitas Laporan Keuangan (Studi Empiris Pada SKPD Kab. Limapuluh Kota ). Jurnal Akuntansi Universitas Negeri Padang, 5(1).

Rukmiyati, N. M. S., dan Budiartha, I. K. (2016). Pengaruh Kualitas Sistem Informasi, Kualitas Informasi Dan Perceived Usefulness Pada Kepuasan Pengguna Akhir Software Akuntansi (Studi Empiris Pada Hotel Berbintang Di Provinsi Bali). E-Jurnal Ekonomi Dan Bisnis Universitas Udayana 5.1, 1, 115-142.

Sadiartha, A. A. N. G. (2017). Lembaga Perkreditan Desa sebagai Penopang KeAjegan Budaya Ekonomi Masyarakat Bali. Jurnal Kajian Bali, 07(02), 1-18. https://doi.org/10.1098/rspb.2007.0281

Sadeghimanesh, Morteza \& Abbas Samadi. (2013) The Effect of IT (Information Technology) on Financial Performance of the Banks Listed in Tehran Stock Exchange. European Online Journal of Natural and Social Sciences,2(3), 2911-2919.

Sapitri, N. made T., Purnamawati, I. G. A., \& Sujana, E. (2015). Pengaruh Kapasitas Sumber Daya Manusia, Pengendalian Internal Akuntansi, Dan 
A.A. Sg. Istri Pradnya Paramitha dan Ida Bagus Dharmadiaksa. Pengaruh...

Pemanfaatan Teknologi Informasi Terhadap Kualitas Laporan Keuangan (Studi Kasus Koperasi Simpan Pinjam Di Kecamatan Buleleng). E-Journal S1 Ak Universitas Pendidikan Ganesha, 3(1), 1-12.

Setiyawati, H. (2013). The Effect of Internal Accountants ' Competence , Managers Commitment to Organizations and the Implementation of the Internal Control System on the Quality of Financial Reporting. International Journal of Business and Management Invention, 2(11), 19-27.

Setyowati, L., Isthika, W., Pratiwi, R. D., \& Nuswantoro, U. D. (2016). FaktorFaktor Yang Mempengaruhi Kualitas Laporan. Jurnal Akuntansi \& Manajemen, 20(1), 179-192.

Sholeh, M. (2017). Pengaruh Kompetensi Akuntansi Pegawai Dan Teknologi Informasi Terhadap Kualitas Laporan Keuangan. Jurnal Bisnis Dan Ekonomi, 8(1), 1-26.

Simon, Yulius, Masdar Mas'ud, Mahfudnurnajamuddin, dan Muhammad Su'un. (2016). The Role Of Apparatus Competence, Internal Control System on Good Governance and The Quality of Financial Statement Information. Journal of Arts, Science \& Commerce, 6(4), 123-132. https://doi.org/10.18843/rwjasc/v7i4/14

Soimah, S. (2014). Pengaruh Kapasitas Sumber Daya Manusia, Pemanfaatan Teknologi Informasi Dan Sistem Pengendalian Intern Pemerintah Terhadap Kualitas Laporan Keuangan Pemerintah Daerah Kabupaten Bengkulu Utara. Jurnal Akuntansi Fakultas Ekonomi Dan Bisnis Universitas Bengkulu.

Suliyantini, Liani, \& Kusmuriyanto. (2017). The Effect of Human Resources Competency and Accrual Based Government Accounting Standard Implementation on the Quality of Local Government Financial Statement with the Implementation of Internal Control System as a. Accounting Analysis Journal, 6(1), 19-26. https://doi.org/10.15294/AAJ.V6I2.15408

Surendran, P. (2012). Technology Acceptance Model: A Survey of Literature. International Journal of Business and Social Research, 2(4), 175-178. https://doi.org/http://dx.doi.org/10.18533/ijbsr.v2i4.161

Wiranata, Ari Arba'a, M. H. dan A. F. M. (2015). Pengaruh Kompetensi Sumber Daya Manusia Dan Pemanfaatan Teknologi Terhadap Kualitas Laporan Keuangan (Studi Empiris UMKM di Kota Padang). Jurnal Akuntansi, 7(1).

Zadeh, M. H. K., Karkon, A., \& Golnari, H. (2015). The Effect of Information Technology on the Quality of Accounting Information system and Its impact on the Quality of Accounting Information. Journal of Finance and Accounting, 3(3), 061-076. 
Zuliarti. (2012). Pengaruh Kapasitas Sumber Daya Manusia, Pemanfaatan Teknologi Informasi, dan Pengendalian Intern Akuntansi Terhadap Nilai Informasi Pelaporan Keuangan Pemerintah Daerah: Studi Pada Pemerintah Kabupaten Kudus. Jurnal Akuntansi Fakultas Ekonomi Dan Bisnis Universitas Muria Kudus. 